\title{
Effect of manufacturing protocol on the internal fit and marginal discrepancy of metal ceramic and full ceramic dental crowns
}

\author{
Katerina V. Geshoska ${ }^{1 *}$, Jagoda Bajevska² \\ ${ }^{I}$ Department of Prosthetic dentistry, Faculty of Dentistry, European University, \\ Saint Clement of Ohrid 68, 1000 Skopje, R. Macedonia \\ ${ }^{2}$ Department of fixed Prosthodontics, Faculty of Dental Medicine, \\ Ss. Cyril and Methodius University, Mother Theresa 43, 1000 Skopje, R. Macedonia
}

Received: December 2017; Accepted: January 2018

\begin{abstract}
The accuracy of internal fit and marginal precision plays important role of clinical quality and success of dental crowns. Complications caused by marginal discrepancies such as caries, gingivitis, hypersensitivity are highlighted in dental literature. Despite marginal fit, internal fit and precision have a significant role in the persistence of full ceramic and metal ceramic crowns. As the technology evolves, it's questionable which impression and manufacturing method is giving most accurate dental crowns.

Therefore, the main purpose of this study is to get some information and data about marginal and internal fitting of dental crowns made by conventional, two-phase impression technique with polyvinyl siloxanes, and using different manufacturing process.
\end{abstract}

Keywords: internal fit, marginal discrepancy, metal ceramic, full ceramic crowns

\section{Introduction}

Precision of internal and marginal gap (MG) plays an important role in the accuracy and success of dental crowns (White et al., 1994). Fixed prosthetic restorations with a poor fitting on prepared tooth are a potential danger, allowing entry and reproduction of oral bacteria that subsequently cause secondary caries and gingivitis (Bader et al., 1991; Knoernschild et al., 2000). Microleakage through dental tubules may lead to pulp inflammation (Felton et al., 1991; Goodacre et al., 2003).

Thus, poor internal and MG of fixed prosthetic restorations, is the reason that reduces their resilience and longevity (Tuntiprawon et al., 1995).

\footnotetext{
*katerinavasilevageshoska@yahoo.com
}

For many years dental researchers examine how the crown fits (Fig. 1). As technology developed, advances and changes happened also in measuring the fit of dental crowns: direct observation, crown sectioning, replica technique, profilometry, image analysis and 3D scanning (Holst et al., 2010; Sorensen et al., 1990). Each method has advantages and disadvantages, but the visual observation is not valid because of subjectivity and tactile sensitivity of the examiner.

All procedures during the manufacturing of the crown require precision and accuracy in order to produce a restoration that fits.

There are new developments in technology that have changed impressions and manufacturing process such as computer-aided design / computer-aided manufacturing system (CAD/CAM). 


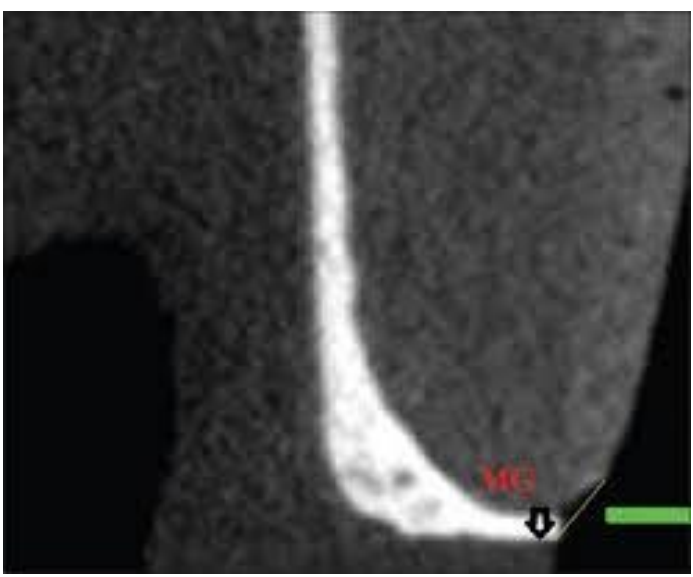

Fig. 1 Microleakage and loss of cement material through the margin of dental crowns (Adopted form Demir et al., 2014).

Dental impressions is one of the key steps for successful prosthetic restoration and they can greatly affect the accuracy of the restoration. The precision of conventional impression depends on the material, type of trays and impression technique that is used.

The literature demonstrates that multiple all-ceramic materials and systems are currently available for clinical use, and there is not a single universal material or system for all clinical situations. The successful application depends upon the clinician to match the materials, manufacturing techniques, and cementation or bonding procedures, with the individual clinical situation (Conrad et al., 2010; Holand et al., 2008).

\section{Material and methods}

To accomplish the objectives in this study, assessment of internal and MG discrepancy of all ceramic and metal ceramic crowns, a single impression technique and three different manufacturing technologies were used. Impression technique is the conventional two-phase impression by using polyvinyl siloxanes (Zhermarck, adition, $\mathrm{C}$ silicones) and custom trays.

Dental crowns were fabricated with these methods: 1) Hot pressed ceramics, IPS E max press Lithium disilicate, Ivoclar Vivadent; 2) Computer-aided design, computer aided manufacturing (Wissner Dental CAD/CAM Blocks of zirconium Wieland Ivoclar Vivadent) and 3) Cast Ni-Cr alloy (Realloy- N+).

Three sets of crowns were made: Group A (5 samples) CAD/CAM of yttrium stabilized tetragonal polycrystalline zirconium (zirconium crowns); Group B (5 samples) IPS E max Press crowns and Group C (5 samples) lost wax and cast of Ni-Cr alloy.

As an in vitro study, we used phantom jaw model in which we prepared five teeth. Teeth preparation is standardized for this type of study with a $1 \mathrm{~mm}$ width, rounded shoulder gingival margin, $6^{0}$ convergence of the walls, $1.5 \mathrm{~mm}$ reduction of the axial tooth substance and $2 \mathrm{~mm}$ occlusal reduction. Preparation was made with standardized diamond bur. Conventional impression was taken with two-step impression techniques using custom tray, putty and light consistency of polyvinyl siloxanes.

Impressions were poured with dental plaster, stone (Elite fast rock, Zhermarck, Germany) prepared according to the instructions of the manufacturer, and stone dies were made. These stone dies will serve to scan, design, and mechanical scraping and cutting zirconium blocks for obtaining zirconium crowns.

E max press copings were fabricated from wax patterns modeled on stone dies. They were invested in phosphate bonded investment. The mould is heated then taken from the furnace and a pellet of presaable ceramic is placed in the mould. Press furnace programme starts and pressed glass ceramics crowns were ready for cleaning with aluminium oxide particles.

For fabricating metal copings stone die will serve as working model for modeling wax patterns. The metal cores were conventionally fabricated (lost wax technique) and cast. They were invested in a phosphate-bonded investment. The investment was removed from the framework and cleaned with aluminum oxide sandblasting.

After the fabrication of crowns we examined their internal fit and marginal discrepancy.

Replica technique is the method that will be used to measure their fitting (Levine,1989). It is a method that uses low-viscosity silicone which fills the inner space of the crown and sets on the prepared tooth. We applied digital pressure to the finishing line, wait three to four minutes for polymerization of the silicone. Its interior has a thin silicone layer which is a replica of the cement layer. In order to measure this layer, we fixed the silicone mass with the putty silicone.

We made cuts with a scalpel in mesial-distal direction.

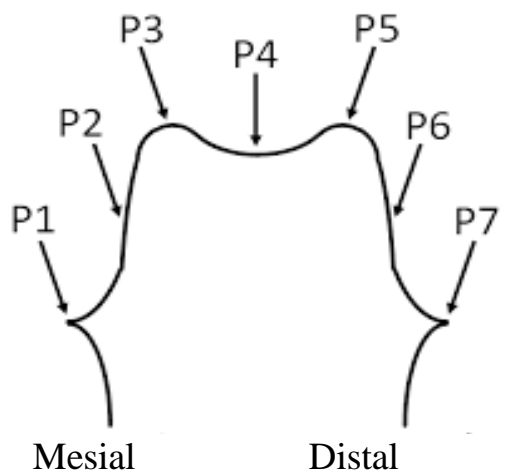

Fig. 2 Illustrated photograph of the measuring points at the cross sections of the silicone mass. 
We measured the thickness of the silicone layer on few reference points: on the margins to measure marginal discrepancy $\mathrm{P} 1$ and $\mathrm{P} 7$, on the axial and occlusal walls to measure the internal fitting P2, P3, P4, P5 and P6 (Fig. 2). Microscopic measurements were made with stereomicroscope (Mitutoyo A221, Japan). Then we calculated mean values and with statistical analysis came to the anticipated results.

\section{Results}

Table 1 shows the width of marginal and internal fit of crowns and mean values in each group measured at all landmarks. The mesial (P1) and distal (P7) measuring points at the cross section of margins showed smallest gap at $\mathrm{E}$ max press and largest discrepancy in metalceramic crowns.

The maximal width for the zirconium group was (P5) $0.416 \mathrm{~mm}$, in the occlusal space. In the metal ceramic crowns maximal width (P1) $0.532 \mathrm{~mm}$ was in the marginal area, and the E max press crowns had (P4) 0.337 $\mathrm{mm}$ in the occlusal space as the maximal width. Measurings of axial space (AS), showed better internal fit in metalceramic crowns compared to others with the means of (P2) and (P6) $0.032 \mathrm{~mm}$ and $0.076 \mathrm{~mm}$ (Fig. 3).

\section{Discussion}

Holmes et al. (1989) claims that the success of a restoration is determined by various factors, among which is the marginal fit of the restoration. Lack of adequate fit is potentially detrimental to both the tooth and the supporting periodontal tissues, due to cement solubility or plaque retention. However, the definitions of marginal fit vary considerably among investigators and often the same term is used to refer to different measurements, or different terms are used to refer to the same measurements.

The replica technique, described initially by McLean and von Fraunhoffer, has been a reliable and valid noninvasive method to determine the adaptation of crowns to tooth-structure. Since then other researchers have used this method to measure crown film thickness. In this study both methods have been used in order to evaluate the effectiveness of each technique to measure the marginal gap. Trifkovic et al. (2012) evaluated precision of different methods to measure marginal fit of dental crowns. The conclusion was that replica technique shows measurements of marginal fit that are statistically significantly lower compared to the values obtained by scanning electron microscopy. The results indicate that

Table 1. Comparison of zirconia CAD/CAM, metalceramic and E max press crowns $(n=5)$

\begin{tabular}{|c|c|c|c|c|}
\hline & Landmark & $\begin{array}{l}\text { Mean } \\
(\mathrm{mm})\end{array}$ & $\begin{array}{l}\text { Minimum } \\
(\mathrm{mm})\end{array}$ & $\begin{array}{l}\text { Maximum } \\
(\mathrm{mm})\end{array}$ \\
\hline \multirow{7}{*}{ 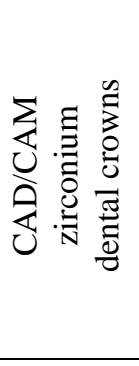 } & $\mathrm{P} 1$ & 0.196 & 0.078 & 0.313 \\
\hline & $\mathrm{P} 2$ & 0.238 & 0.140 & 0.335 \\
\hline & P3 & 0.188 & 0.143 & 0.232 \\
\hline & $\mathrm{P} 4$ & 0.284 & 0.191 & 0.376 \\
\hline & P5 & 0.321 & 0.226 & 0.416 \\
\hline & P6 & 0.150 & 0.069 & 0.230 \\
\hline & $\mathrm{P} 7$ & 0.180 & 0.073 & 0.287 \\
\hline \multirow{7}{*}{ 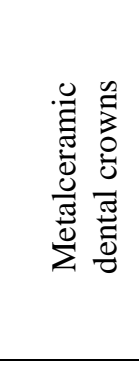 } & $\mathrm{P} 1$ & 0.296 & 0.060 & 0.532 \\
\hline & $\mathrm{P} 2$ & 0.032 & 0.025 & 0.039 \\
\hline & P3 & 0.390 & 0.346 & 0.433 \\
\hline & $\mathrm{P} 4$ & 0.393 & 0.300 & 0.485 \\
\hline & P5 & 0.346 & 0.289 & 0.403 \\
\hline & P6 & 0.076 & 0.056 & 0.096 \\
\hline & $\mathrm{P} 7$ & 0.136 & 0.040 & 0.232 \\
\hline \multirow{7}{*}{ 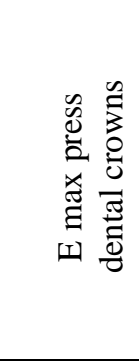 } & $\mathrm{P} 1$ & 0.166 & 0.062 & 0.270 \\
\hline & $\mathrm{P} 2$ & 0.046 & 0.000 & 0.091 \\
\hline & P3 & 0.167 & 0.069 & 0.265 \\
\hline & $\mathrm{P} 4$ & 0.253 & 0.168 & 0.337 \\
\hline & P5 & 0.272 & 0.233 & 0.310 \\
\hline & P6 & 0.064 & 0.009 & 0.119 \\
\hline & $\mathrm{P} 7$ & 0.110 & 0.070 & 0.150 \\
\hline
\end{tabular}

Макед. фарм. билт., 63 (1) 69 - 74 (2017) 


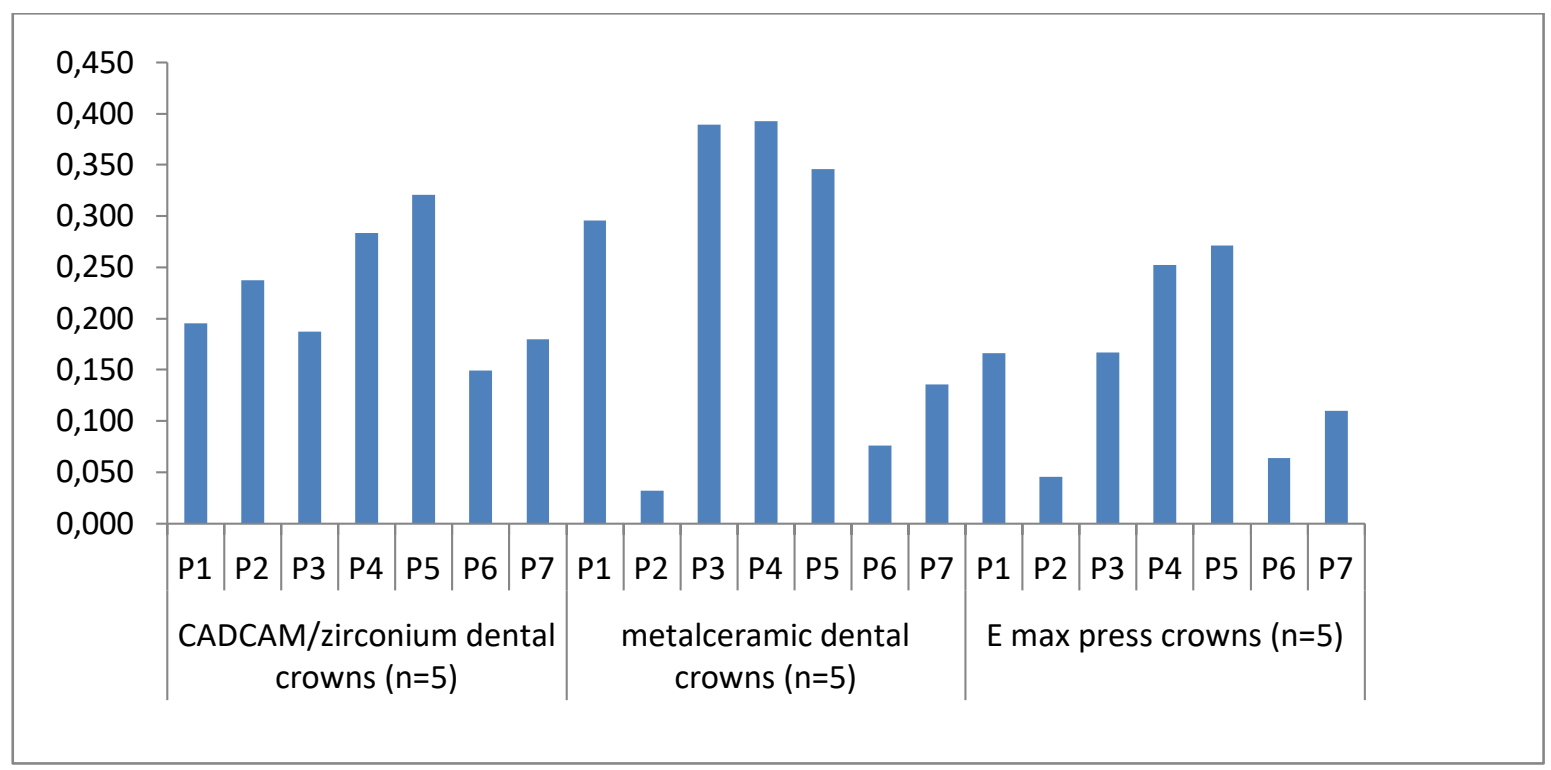

Fig. 3 The mean values of marginal and internal widths measured at all landmarks.

the choice of technique for measuring the accuracy of ceramic crowns influences the final results of the study.

Researchers were using replica technique to measure fitting of the crowns (Boening et al., 2000; Molin et al., 1993). The main limitation of this method is distortion, even damage of the material during handling.

Holden et al. (2009) were comparing metal ceramic crowns, leucite reinforced ceramic pressed to metal and leucite reinforced glass ceramic crown. All crowns were examined microscopically with $\mathrm{x} 45$ magnification. The results showed the worst marginal closing is in metalceramic crowns, and most accurate in leucite glass ceramics pressed on metal crowns.

Most researchers continue to use the criteria established by McLean and von Fraunhofer for evaluating a clinically acceptable largest marginal gap width. Considering this only the amount of marginal discrepancies of conventional group are within the clinically acceptable range of $120 \mu \mathrm{m}$ (Mclean et al., 1971). But Moldovan et al. (2006) rated the values of 100 $\mu \mathrm{m}$ for marginal misfit as good and values of 200-300 $\mu \mathrm{m}$ as acceptable. Therefore, the marginal accuracies, represented by the absolute marginal discrepancy and measured in the present study, could be rated as good for all ceramic crowns and acceptable for metal ceramic group.

Theoretically, the internal space nedeed for the cement is 20 to $40 \mu \mathrm{m}$ (Levine, 1989), and an internal space between 50 to $100 \mu \mathrm{m}$ has been considered acceptable (Ishikiriama et al., 1981).

All groups of crowns show bigger occlusal interspace, P3 and P5, due to the spacer that was placed during the laboratory process in these areas to prevent sharp internal angles of the crown. The less occlusal space of the lithium disilicate material is significantly smaller because it leads to fractures or cracks. Beuer et al. (2009) reported that the internal relief, die space, which is added about $5 \mu \mathrm{m}$ space at the chamfer area, results in better seating at the margin. Bindle and Mormann (2005) found that greater internal relief results in less marginal gap, which can lead to less premature contact internally.

Finally, though marginal fit has been associated with marginal gingivitis, is highlighted in many studies. Internal and occlusal fit play also a significant role on structural durability of all-ceramic and metal ceramic crowns with the cement space which influences the retention of fixed prostheses. Further researching of crowns manufacturing techniques are necessary, and the relation between the reliability of crowns and the internal fit could be the topic of future studies.

\section{Conclusion}

In this study we evaluated the in vitro accuracy of marginal and internal fit of all-ceramic crowns ( $E$ max press and yttria-stabilized tetragonal zirconia polycrystals crowns) and metal ceramic crowns. E max press crowns showed best fitting compared to yttria-stabilized tetragonal zirconia polycrystals, and metal ceramic crowns. E max press and yttria-stabilized tetragonal zirconia polycrystals showed acceptable and metal ceramic non acceptable marginal fitting. Among groups all crowns had fitting differences within marginal P1, P7 and occlusal fitting P3, P4, P5.

The pressed ceramics had the slightest deformation in the manufactoring process, while the casting of the metal proved to be the most unappropriate method for 
making crowns. However, further research is needed to determine which method and which combination of the impression method and method of production results in the most accurate crowns.

\section{References}

Bader, J., Rozier, R., Mcfall, W., 1991. Effect of crown margins on periodontal conditions in regularly attending patients. J. Prosthet. Dent. 65, 75-79. Available at: https://doi.org/10.1016/0022-3913(91)90053-y.

Beuer, F., Naumann, M., Gernet, W., Sorensen, J.A., 2009. Precision of fit: zirconia three-unit fixed dental prostheses. Clin. Oral. Investig. 13, 343-349. Available at: https://doi.org/10.1007/s00784-008-0224-6.

Bindl, A., Mörmann, W.H., 2005. Marginal and internal fit of all-ceramic CAD/CAM crown-copings on chamfer preparations. J. Oral. Rehabil. 32, 441-447. Available at: https://doi.org/10.1111/j.1365-2842.2005.01446.x.

Boening, K.W., Wolf, B.H., Schmidt, A.E., Kastner, K., Walter, M.H., 2000. Clinical fit of proceraAllCeram crowns. J. Prosthet. Dent. 84(4), 419-424. Available at: https://doi.org/10.1067/mpr.2000.109125.

Conrad, H.J., Seong, W.J., Pesun, I.J., 2007. Current ceramic materials and systems with clinical recommendations: A systematic review. J. Prosthet. Dent. 98(5), 389-404. Available at: https://doi.org/10.1016/S0022-3913(07)60124-3.

Demir, N., Ozturk, A. N., Malkoc, M. A., 2014. Evaluation of the marginal fit of full ceramic crowns by the microcomputed tomography (micro-CT) technique. European Journal of Dentistry 8(4), 437-444. Available at: https://doi.org/10.4103/1305-7456.143612.

Felton, D.A., Kanoy, B.E., Bayne, S.C., 1991. Effect of in vivo crown margin discrepancies on periodoontal health. J. Prosthet. Dent. 65, 357-364. Available at: https://doi.org/10.1016/0022-3913(91)90225-1.

Goodacre, C.J., Bernal, G., Rungcharassaeng, K., 2003. Clinical complications in fixed prosthodontics. J. Prosthet. Dent. 90, 31-41. Available at: https://doi.org/10.1016/s00223913(03)00214-2.

Holand, W., Schweiger, M., Watzke, R., Peschke, A., Kappert, H., 2008. Ceramics as biomaterials for dental restoration. Expert Rev. Med. Devices 5(6), 729-745. Available at: https://doi.org/10.1586/17434440.5.6.729.

Holden, J.E., Goldstein, G.R., Hittelman, E.L., Clark, E.A., 2009. Comparison of the marginal fit of pressable ceramic to metal ceramic restorations. J. Prosthodont. 18(8), 645652. Available at:
https://doi.org/10.1111/j.1532-849X.2009.00497.x.

Holmes,. J.R., Bayne, S.C., Holland, G.A., Sulik, W.D., 1989. Considerations in measurement of marginal fit. The Journal of Prosthetic Dentistry 62, 405-408. Available at: https://doi.org/10.1016/0022-3913(89)90170-4.

Holst, S., Tawdrous, R.E., Karl, M., 2010. Description of a novel technique for threedimensional fit assessment of dental restorations. 6th world congress of biomechanics, IFMBE proceedings. Singapore. Springer; 20.

Ishikiriama, A., Oliveira, J.F., Vieira, D.F., Mondelli, J., 1981. Influence of some factors on the fit of cemented crowns. J. Prosthet. Dent. 45, 400-404. Available at: https://doi.org/10.1016/0022-3913(81)90100-1.

Knoernschild, K.L., Campbell, S.D., 2000. Periodontal tissue responses after insertion of artificial crowns and fixed partial dentures. J. Prosthet. Dent. 84, 492-498. Available at: https://doi.org/10.1067/mpr.2000.110262.

Levine, W.A., 1989. An evaluation of the film thickness of resin luting agents. J. Prosthet. Dent. 62, 175-178. Available at: https://doi.org/10.1016/0022-3913(89)90308-9.

Levine, W.A., 1989. An evaluation of the film thickness of resin luting agents. J. Prosthet. Dent. 62, 175-178. Available at: https://doi.org/10.1016/0022-3913(89)90308-9.

McLean, J.W., von Fraunhofer, J.A., 1971. The estimation of cement film thickness by an in vivo technique. Br. Dent. J. 131, 107-111. Available at: https://doi.org/10.1038/sj.bdj.4802708.

Moldovan, O., Rudolph, H., Quaas, S., Bornemann, G., Luthardt, R.G., 2006. Internal and external fit of CAMmade zirconia bridge frameworks-a pilot study. Dtsch. Zahnärztl. Z. 61, 38-42.

Molin, M., Karlsson, S., 1993. The fit of gold inlays and three ceramic inlay systems. A clinical and in vitro study. Acta Odontol. Scand. 51(4), 201-206. Available at: https://doi.org/10.3109/00016359309040568.

Sorensen, J.A., 1990. A standardized method for determination of crown margin fidelity. J. Prosthet. Dent. 64(1), 18-24. Available at: https://doi.org/10.1016/0022-3913(90)901475.

Trifkovic, B., Budak, I., Todorovic, A., Hodolic, J., Puskar, T., Jevremovic, D., Vukelic, D., 2012. Application of replica technique and SEM in accuracy measurement of ceramic crowns. Measurement Science Review 12(3), 90-97.

Tuntiprawon, M., Wilson, T., 1995. The effect of cement thickness on the fracture strength of all-ceramic crowns. Aust. Dent. J. 40, 17-21. Available at: https://doi.org/10.1111/j.1834-7819.1995.tb05607.x.

White, S.N., Ingles, S., Kipnis,V., 1994. Influence of marginal opening on microleakage of cemented artificial crowns. J. Prosthet. Dent. 71(3), 257-264. Available at: https://doi.org/10.1016/0022-3913(94)90464-2. 


\title{
Резиме
}

\section{Улогата на производствениот процес во внатрешно налегнување и маргинална дискрепанца кај металкерамички и целосно керамички коронки}

\author{
Катерина Василева Гешоска ${ }^{1}$, Јагода Бајевска ${ }^{2}$ \\ ${ }^{1}$ Клиника за стоматолошка протетика, Факултет за стоматологија, \\ Европски Универзитет, Св. Климент Охридски 68, 1000 Скопје, Р. Македонија \\ ${ }^{2}$ Клиника за стоматолошка протетика, Факултет за стоматологија, \\ Универзитет „Св. Кирил и Методиј”, Мајка Тереза 43, 1000 Скопје, Р. Македонија
}

Клучни зборови: внатрешно налегнување, маргинална дискрепанца, металкерамички, целосно керамички коронки

Прецизноста на внатрешното налегнување и маргинална прецизност играат важна улога во клиничкиот квалитет и успех на денталните коронки. Компликациите предизвикани од несоодветна маргинална прецизност како кариес, гингивит и хиперсензитивност се често спомнувани со стоматолошката литература. Покрај маргиналното налегнување, внатрешното налегнување и прецизност имаат значајна улога во трајноста на целосната керамика и металкерамичките коронки. Како што технологијата се развива, дискутабилно е кој метод на отпечатување и метод на производство на коронката резултира со поточна коронка.

Затоа, главната цел на оваа студија е да се добијат некои информации и податоци за внатрешното и маргинално налегнување на денталните коронки изработени со конвенционално, двофазно отпечатување, со користење на поливинил силоксани, и различен производствен процес. 